Egyptian Journal of Aquatic Biology \& Fisheries

Zoology Department, Faculty of Science,

Ain Shams University, Cairo, Egypt.

ISSN $1110-6131$

Vol. 24(4): 89 - 101 (2020)

www.ejabf.journals.ekb.eg

\title{
Analysis of the determinants of Fish Foreign Trade in Egypt
}

\author{
Yaseen E. Abdul-Tawab ${ }^{1 *}$, Mohamed A. Ahmed ${ }^{2}$ \\ ${ }^{1}$ National Institute of Oceanography and Fisheries \\ ${ }^{2}$ Department of Agricultural Economics, Faculty of Agriculture, Fayoum University \\ *Corresponding Author: yaseen8090@yahoo.com
}

\section{ARTICLE INFO}

Article History:

Received: April 22, 2020

Accepted: May 30, 2020

Online: June 2020

\section{Keywords:}

Fish Foreign Trade,

Double Logarithmic

Model,

Coverage rate,

Trade balance.

\section{INTRODUCTION}

Fish is considered among the most necessary food commodities as it is one of the sources of obtaining animal protein needed for human food, as well as a substitute for meat and poultry (Nawar, 1976). Foreign trade sector plays an important role in economic development in many developing countries, where exports contribute positively to the national income and create a balanced growth in the development process (Suleiman, 2016). 
Fish and fishery products play an important role in Egypt's food security and domestic economy (Feidi, 2003). Despite the increase in domestic production of fish during the past years, Egypt still faces a deficit in meeting consumption needs, which is covered by imports that was estimated by about 367 thousand tons, and valued at more than 10.09 billion pound in 2017.

Although the total domestic fish production from various fisheries has increased in recent years as a result of increased aquaculture activities and fish imports, still consumption needs are constantly increasing and a fish food gap in quantity and value has been raising over time due to the increase in population, the increase in consumption as a result of the change in traditional attitude of preference form meat and poultry to fish, the importation of low priced fish species, and the increasing in purchasing power of some sectors of population who consume high quantities of fish (Feidi, 2003).

\section{Research Problem:}

Egypt faces a fish gap reached about 367 thousand tons in 2017, with a rate of selfsufficiency of about $84.61 \%$ in the same year (GAFRD, 2017), this is due to the increase in the local demand for fish as a result of population growth and the high rate of per capita consumption of Fish that amounted to about $14.64 \mathrm{~kg}$ in 2000 and increased to about 20.72 in 2017, and consequently the imports amount and value of fish to meet the deficit in domestic production has been increased. The percentage of Egyptian exports covering imports of fish in 2017 was about 6.4\%, which indicates a large trade gap, and a deficit in the Egyptian fish trade balance, despite the expansion of the Egyptian natural fisheries area and fish farming, which could achieve self-sufficiency and even a surplus of fish for export. Thus the problem is outlined by the high value of a deficit in the Egyptian fish trade balance, as a reason for the high value of Egyptian fish imports which explains the need for studying the foreign fish trade in Egypt.

\section{Research objectives:}

The research aims at studying the following objectives:

1- Studying the current situation of the Egyptian fish foreign trade.

2- Studying the current status of local production, fish gap, self-sufficiency ratio and per capita fish consumption in Egypt.

3- Modeling the most important factors influencing Egyptian fish imports and exports.

4- Evaluating the Egyptian fish trade structure.

\section{MATERIALS AND METHODS}

The study relied on the descriptive and quantitative economic analysis in achieving its objectives, where averages, percentages, growth equations; annual growth rates, regression model and total and price coverage rates were used.

The study relied on publications issued by the General Authority for Fish Resources Development (GAFRD) and the Central Agency for Public Mobilization and Statistics (CAPMAS), Research and previous studies related to the subject of the research. 


\section{RESULTS AND DISCUSSION}

\section{A glance into the global fish market:}

Global total production was estimated by about 172.6 million tons, where the production of capture fisheries reached about 92.5 and the production of aquaculture reached about 80.1 million tons. The global trade value of fish was estimated by about 155.7 billion USD in 2017. Per capita food consumption of food fish was estimated by about $20.3 \mathrm{~kg} /$ year, $9.7 \mathrm{~kg}$ from capture fisheries and $10.6 \mathrm{~kg}$ from aquaculture.

Table 1. World Fish market in 2017

\begin{tabular}{|l|c|c|}
\hline Production & 172.6 & \multirow{2}{*}{ Million tons } \\
\cline { 1 - 2 } Capture fisheries & 92.5 & \\
\hline Aquaculture & 80.1 & \multirow{2}{*}{ Billion USD } \\
\hline Trade value & 155.7 & \multirow{3}{*}{ (kg/year) } \\
\cline { 1 - 2 } Per capita food consumption of food fish & 20.3 & \\
\hline From capture fisheries & 9.7 & \\
\cline { 1 - 2 } From aquaculture & 10.6 & \\
\cline { 1 - 2 }
\end{tabular}

Source: globefish highlights: a quarterly update on world seafood markets, FAO, 2019.

\section{Fish trade structure in Egypt:}

Egypt is generally considered as an imported fish country despite the abundance of fish production factors such as the huge natural fish water resources which exceed 13.9 million acres (Abdel Tawab, 2016) in addition to fish farming where Egypt occupied an advanced position among the other countries.

Consequently, this leads to an increase in the annual local fish production, but this production is still less than the targeted one in comparison to consumption due to the increasing demand for fish, which created a fish food gap that being covered by importing from abroad, and was a direct reason for Egyptian fish exports' retreating, where exports depend on luxury fish with high prices in return for importing economical varieties of low price and nutrient value.

\subsection{Egyptian fish imports' trend:}

It is indicated from table 2. that the annual Egyptian fish imports fluctuated between increase and decrease during the period (2000-2017), where imports ranged between a minimum of about 136 thousand tons in 2009, and a maximum of about 584 thousand tons in 2014, with an average of about 250.5 thousand tons during the same period.

This fluctuation in fish imports is due to the increase in self-sufficiency ratio of fish, which rose from about $77.3 \%$ in 2000 to about $86.63 \%$ in 2016 as a result of the growing in domestic fish production which rose from about 724 thousand tons in 2000 to about 1.8 Million tons in 2017.

The value of fish imports has grown from 476 million pounds in 2000 to 10.09 billion pounds in 2017 which obviously show the amount of what the balance of 
payments bears as a value of imported fish, which negatively affects development plans in Egypt at the future.

The analysis of trade determinants is particularly very important for both aquaculture and fisheries sectors. Where both developed countries, which are main importers, and developing countries, which are depending on fish trade as a source of income (Fabrizio, et al., 2015).

Table 2. Factors influencing Egyptian fish imports during the period (2000-2017)

\begin{tabular}{|c|c|c|c|c|c|c|c|}
\hline year & $\begin{array}{c}\text { Fish } \\
\text { imports' } \\
\text { quantity } \\
\text { (Thousand } \\
\text { tons) } \\
\end{array}$ & $\begin{array}{c}\text { Fish } \\
\text { imports' } \\
\text { value } \\
\text { (million } \\
\text { pound) }\end{array}$ & $\begin{array}{l}\text { Domestic } \\
\text { fish } \\
\text { production } \\
\text { (Thousand } \\
\text { tons) }\end{array}$ & $\begin{array}{c}\text { Dollar } \\
\text { exchange } \\
\text { rate }\end{array}$ & $\begin{array}{c}\text { Population } \\
\text { (Thousand } \\
\text { people) }\end{array}$ & $\begin{array}{l}\text { Per capita } \\
\text { fish } \\
\text { consumption } \\
\text { (Kg) }\end{array}$ & $\begin{array}{c}\text { Self- } \\
\text { sufficiency } \\
\text { ratio } \%\end{array}$ \\
\hline 2000 & 213.63 & 476.41 & 724 & 3.7 & 63976 & 14.64 & 77.29 \\
\hline 2001 & 261 & 533.92 & 772 & 3.98 & 65336 & 15.79 & 74.78 \\
\hline 2002 & 154 & 423.97 & 801 & 4.52 & 66668 & 14.3 & 84.07 \\
\hline 2003 & 163 & 543.56 & 876 & 5.98 & 67976 & 15.24 & 84.57 \\
\hline 2004 & 221 & 755.12 & 865 & 5.98 & 69330 & 15.63 & 79.8 \\
\hline 2005 & 189 & 523.59 & 889 & 5.88 & 69997 & 15.32 & 82.9 \\
\hline 2006 & 208 & 593.07 & 971 & 5.75 & 70653 & 16.62 & 82.67 \\
\hline 2007 & 259 & 1221.89 & 1008 & 5.67 & 74357 & 16.98 & 79.84 \\
\hline 2008 & 137 & 2034.89 & 1068 & 5.53 & 75097 & 15.95 & 89.14 \\
\hline 2009 & 136 & 2407.74 & 1093 & 5.55 & 76823 & 15.89 & 90.64 \\
\hline 2010 & 257 & 2780.59 & 1305 & 5.96 & 78728 & 19.7 & 84.13 \\
\hline 2011 & 182 & 3106.08 & 1362 & 5.71 & 80410 & 19.09 & 88.75 \\
\hline 2012 & 335 & 4768.90 & 1372 & 6 & 82305 & 20.55 & 81.12 \\
\hline 2013 & 236 & 2984.49 & 14540 & 6.91 & 84628 & 19.73 & 87.1 \\
\hline 2014 & 584 & 5354.32 & 1482 & 7.18 & 86811 & 23.47 & 72.72 \\
\hline 2015 & 296 & 5752.97 & 1519 & 7.61 & 88958 & 20.18 & 84.61 \\
\hline 2016 & 311 & 4804.76 & 1706 & 8.88 & 91023 & 21.64 & 86.63 \\
\hline 2017 & 367 & 10087.3 & 1823 & 18.03 & 94799 & 22.72 & 84.61 \\
\hline Average & 250.53 & 2730.75 & 1898.67 & 6.60 & 77104.2 & 17.96 & 83.07 \\
\hline
\end{tabular}

Source: General Authority for Fish Resources Development, Fish Statistics Book, separate numbers

Factors that affect the amount of imported fish have been studied in order to reduce fish imports. Despite the impact of such factors, some of them can't be controlled as it is external ones whose impact can't be easily reduced, while others are desirable factors and there is a must to increase them. The following are most important factors that affect the amount of fish imports (Suleiman, 2016):

- International fish prices: The price changes of fish species are attributed to many factors, most important of which are demand for fish, social factors, 
customs, traditions and government administrative factors that determine production in addition to export prices as the price is a main variable that affects the quantity required of the commodity.

- Fish's domestic production: The amount of fish's domestic production in the same year is an important determinant of the amount of imports, however, the local production of fish is sometimes not the determinant of the imports amount in case of the quantity of imports is subject to other variables such as the price of imports or the level of individual income.

- Population: There is no doubt that the population in any country is the main determinant of the amount of consumption of various commodities in this country, therefore it is expected that consumption will increase as a result of population growth and reverse migration (Abdel Tawab, 2016).

- Fish available for consumption: is one of the factors affecting fish imports, where domestic production of fish may increase unexpectedly and with a large amount of imports which makes a surplus of consumption and leads to an increase in the availability of consumption in the following year.

- Average per capita income: Fish is considered a necessary commodity in Egypt, it provides the individual with an adequate amount of animal protein and other necessary elements, it also has its own taste and is considered an alternative to red meat and poultry, therefore it is expected that the increases in Individual income will lead to a corresponding increase in fish consumption.

\subsubsection{Growth equations of factors influencing Egyptian fish imports:}

As shown from growth equations in table 3., fish imports' quantity increased by an annual growth of $3.9 \%$ during the period (2000-2017), while fish Imports' value increased by an annual growth rate of $18.9 \%$, fish domestic production increased by an annual growth rate of $7.5 \%$, and per capita fish consumption increased by an annual growth rate of $2.8 \%$, where all equations for the above growth rates are statistically significant at level (0.01), while self-sufficiency ratio of fish\% increased by an annual growth rate of $0.3 \%$ but is not statistically significant.

Table 3. Growth equations of factors influencing Egyptian fish imports during the period (2000-2017)

\begin{tabular}{|c|c|c|c|c|c|}
\hline Item & Equation & $\mathbf{T}$ & $\mathbf{R}^{2}$ & $\mathbf{F}$ & $\begin{array}{c}\text { Annual growth } \\
\text { rate } \%\end{array}$ \\
\hline Fish imports' quantity & $Y=5.1 X^{0.039}$ & $(2.74)^{* *}$ & 0.32 & $(7.55)^{* *}$ & 3.9 \\
\hline Fish imports' value & $Y=5.65 X^{0.189}$ & $(13.89)^{* *}$ & 0.92 & $(193)^{* *}$ & 18.9 \\
\hline Domestic fish production & $Y=6.44 X^{0.075}$ & $(3)^{* *}$ & 0.36 & $(9)^{* *}$ & 7.5 \\
\hline Dollar exchange rate & $Y=1.34 X^{0.051}$ & $(5.33) * *$ & 0.64 & $(28.4)^{* *}$ & 5.1 \\
\hline Population & $Y=11 X^{0.023}$ & $(46)^{* *}$ & 0.99 & $(2147)^{* *}$ & 2.3 \\
\hline $\begin{array}{l}\text { Per capita fish } \\
\text { consumption }\end{array}$ & $Y=2.6 X^{0.028}$ & $(9.6) * *$ & 0.85 & $(92.2)^{* *}$ & 2.8 \\
\hline Self-sufficiency ratio & $Y=4.38 X^{0.003}$ & 1.3 & 0.1 & 1.69 & 0.3 \\
\hline
\end{tabular}

** Significant at level (0.01), * Significant at level (0.05), $\mathrm{Y}=$ estimated value of the studied variable, $\mathrm{X}=$ time or years, Source: calculated from Table (2) 


\subsubsection{Modeling the most important factors influencing Egyptian fish imports:}

Factors such as fish imports' value, fish domestic production, dollar exchange rate, population, per capita fish consumption, and fish self-sufficiency ratio $\%$, were used in a regression model to determine which of these factors influencing the imported quantity of fish. Using both linear and double logarithmic model (stepwise regression method) (Allen, 1972), factors that influencing Egyptian fish imports during the period (20002017) are found as the following:

\section{- The Linear Model:}

Per capita fish consumption $\left(\mathrm{X}_{5}\right)$ and fish self-sufficiency ratio\% $\left(\mathrm{X}_{6}\right)$ are the most influencing factors on the fish imports' quantity, while other factors are not significantly influencing it.

$Y=753+28.58 X_{5}-12.24 X_{6}$

Where;

Y= Fish Imports' quantity,

$\mathrm{X}_{5}=$ Per capita fish consumption,

$\mathrm{X}_{6}=$ Fish Self-sufficiency ratio\%.

\section{- The Double Logarithmic Model:}

Fish self-sufficiency ratio\% $\left(\mathrm{X}_{6}\right)$ and population $\left(\mathrm{X}_{4}\right)$ are the most influencing factors on the fish imports' quantity, while other factors are not significantly influencing it.

$\operatorname{Ln} Y=-0.2-5.17 \operatorname{Ln} X_{6}+2.5 \operatorname{Ln} X_{4}$

Where;

$\mathrm{Y}=$ Fish Imports' quantity,

$\mathrm{X}_{6}=$ Fish Self-sufficiency ratio\%,

$\mathrm{X}_{4}=$ Population.

Table 4. Linear and Logarithmic regression model of factors influencing Egyptian fish imports during the period (2000-2017)

\begin{tabular}{|c|c|c|}
\hline Variables & Linear Model & Double Logarithmic Model \\
\hline Constant & 753 & -0.2 \\
\hline Fish imports' value (x1) & - & - \\
\hline Domestic fish production (x2) & - & - \\
\hline Dollar exchange rate (x3) & - & - \\
\hline Population (x4) & - & $(19.7)^{* *}$ \\
\hline Per capita fish consumption (x5) & 28.58 & - \\
\hline Fish self-sufficiency ratio\% (x6) & -12.24 & -5.17 \\
\hline $\mathrm{F}$ & $(-10.43)^{* *}$ & $(-19.7)^{* *}$ \\
\hline $\mathrm{R}^{-2}$ & 169.3 & 304 \\
\hline $\mathrm{DW}$ & 0.95 & 0.97 \\
\hline
\end{tabular}

Dependent Variable (Y): Fish imports' quantity- Stepwise regression method - Confidence Intervals Level 95\% - Significance level (0.05) 
According to the results of double Logarithmic model, factors influencing Egyptian fish imports are respectively Fish self-sufficiency ratio\% and Population. The results indicated that the increase of Fish self-sufficiency ratio\% in Egypt by 10\%, will lead to a decrease in fish Imports' quantity by $51.7 \%$. An increase in population of Egypt by $10 \%$ will lead to an increase in fish Imports' quantity by $25 \%$.

\subsection{Egyptian fish exports' trend:}

It is clear from the data of table 5. that Egypt's exports of fish are few and the quantity fluctuated annually between increase and decrease during the study period (2000-2017), as it ranged between a minimum of about 0.96 thousand tons in 2000, and a maximum of about 47.8 thousand tons in 2016, with an annual average of 12.4 thousand tons.

The value of Egyptian fish exports fluctuated also during the study period; it reached to a maximum value of about 649.5 million pounds in 2017 , while it reached to a minimum of about 4.13 million pounds in 2000, with an annual average of about 176.7 million pounds.

Table 5. Factors influencing Egyptian fish exports during the period (2000-2017)

\begin{tabular}{|c|c|c|c|c|c|}
\hline years & $\begin{array}{c}\text { Fish exports' } \\
\text { quantity } \\
\text { (ton) }\end{array}$ & $\begin{array}{c}\text { Fish exports' } \\
\text { value } \\
\text { (million pound) }\end{array}$ & $\begin{array}{c}\text { Domestic fish } \\
\text { production } \\
\text { (Thousand } \\
\text { tons) }\end{array}$ & $\begin{array}{c}\text { Self- } \\
\text { sufficiency } \\
\text { ratio\% }\end{array}$ & $\begin{array}{c}\text { Dollar } \\
\text { exchange } \\
\text { rate }\end{array}$ \\
\hline 2000 & 960 & 4.13 & 724 & 77.29 & 3.7 \\
\hline 2001 & 1220 & 5.12 & 772 & 74.78 & 3.98 \\
\hline 2002 & 2560 & 9.98 & 801 & 84.07 & 4.52 \\
\hline 2003 & 3130 & 18.47 & 876 & 84.57 & 5.98 \\
\hline 2004 & 1910 & 5.54 & 865 & 79.8 & 5.98 \\
\hline 2005 & 5120 & 23.04 & 889 & 82.9 & 5.88 \\
\hline 2006 & 4050 & 19.44 & 971 & 82.67 & 5.75 \\
\hline 2007 & 4420 & 25.64 & 1008 & 79.84 & 5.67 \\
\hline 2008 & 6730 & 126.52 & 1068 & 89.14 & 5.53 \\
\hline 2009 & 7590 & 139.66 & 1093 & 90.64 & 5.55 \\
\hline 2010 & 10600 & 190.80 & 1305 & 84.13 & 5.96 \\
\hline 2011 & 9490 & 139.50 & 1362 & 88.75 & 5.71 \\
\hline 2012 & 15810 & 270.35 & 1372 & 81.12 & 6 \\
\hline 2013 & 20450 & 366.06 & 14540 & 87.1 & 6.91 \\
\hline 2014 & 28000 & 518.00 & 1482 & 72.72 & 7.18 \\
\hline 2015 & 19000 & 235.60 & 1519 & 84.61 & 7.61 \\
\hline 2016 & 47810 & 432.68 & 1706 & 86.63 & 8.88 \\
\hline 2017 & 35110 & 649.54 & 1823 & 84.61 & 18.03 \\
\hline Average & $\mathbf{1 2 4 4 2}$ & $\mathbf{1 7 6 . 6 7}$ & $\mathbf{1 8 9 8 . 6 7}$ & $\mathbf{8 3 . 0 7}$ & $\mathbf{6 . 6 0}$ \\
\hline
\end{tabular}

Source: General Authority for Fish Resources Development, Fish Statistics Book, separate numbers.

\subsubsection{Growth equations of factors influencing Egyptian fish exports:}

As shown from growth equations in table 6., fish exports' quantity increased by an annual growth of $18.6 \%$ during the period (2000-2017), while fish exports' value increased by an annual growth rate of $28 \%$, fish domestic production increased by an 
annual growth rate of $7.5 \%$, where all equations for the above growth rates are statistically significant at level (0.01), while self-sufficiency ratio of fish\% increased by an annual growth rate of $0.3 \%$ and is not statistically significant.

Table 6. Growth equations of factors influencing Egyptian fish exports during the period (2000-2017)

\begin{tabular}{|c|c|c|c|c|c|}
\hline Item & Equation & $\mathbf{T}$ & $\mathbf{R}^{2}$ & $\mathbf{F}$ & $\begin{array}{l}\text { Annual } \\
\text { growth } \\
\text { rate } \%\end{array}$ \\
\hline $\begin{array}{l}\text { Fish exports' } \\
\text { quantity }\end{array}$ & $Y=7 X^{0.186}$ & $(11)^{* *}$ & 0.88 & $(124)^{* *}$ & 18.6 \\
\hline Fish exports' value & $Y=1.42 X^{0.280}$ & $(10)^{* * *}$ & 0.85 & $(101)^{* *}$ & 28 \\
\hline $\begin{array}{l}\text { Domestic fish } \\
\text { production }\end{array}$ & $Y=6.44 X^{0.075}$ & $(3)^{* *}$ & 0.36 & $(9) * *$ & 7.5 \\
\hline Dollar exchange rate & $Y=1.34 X^{0.051}$ & $(5.33)^{* *}$ & 0.64 & $(28.4)^{* *}$ & 5.1 \\
\hline Self-sufficiency ratio & $Y=4.38 X^{0.003}$ & 1.3 & 0.1 & 1.69 & 0.3 \\
\hline
\end{tabular}

** Significant at level (0.01), * Significant at level (0.05), $\mathrm{Y}=$ estimated value of the studied variable, $\mathrm{X}=$ time or years, Source: calculated from table (5)

\subsubsection{Modeling the most important factors influencing Egyptian fish exports:}

Factors such as Fish exports' value, Fish domestic production, Dollar exchange rate, and Fish self-sufficiency ratio\%, were used in a regression model to determine which of these factors influencing the exported quantity of fish. Using both a linear and double logarithmic model (stepwise regression method), factors that influencing Egyptian fish exports during the period (2000-2017) are found as the following:

- The Linear Model:

Fish Exports' value $\left(\mathrm{x}_{1}\right)$ is the only factor influencing on the fish exports' quantity, while other factors are not significantly influencing it.

$Y=1832+0.06 X_{1}$

Where;

$Y=$ Fish Exports' quantity,

$\mathrm{X}_{1}=$ Fish Exports'value.

- The Double Logarithmic Model:

Fish Exports' value $\left(\mathrm{x}_{1}\right)$ and Fish self-sufficiency ratio\% $\left(\mathrm{X}_{4}\right)$ are the most influencing factors on the fish exports' quantity, while other factors are not significantly influencing it.

$\operatorname{Ln} Y=5.4+0.55 \operatorname{Ln} X_{1}+0.65 L n X_{4}$

Where;

Y= Fish Exports' quantity,

$\mathrm{X}_{1}=$ Fish Exports' value,

$\mathrm{X}_{4}=$ Fish Self-sufficiency ratio $\%$.

According to double Logarithmic model, factors influencing Egyptian fish exports are respectively Fish Exports' value and Fish self-sufficiency ratio\%. The results indicate 
that the increase of Fish Exports' value by $10 \%$, will lead to an increase in fish exports' quantity by $5.5 \%$. While increasing fish self-sufficiency ratio\% in Egypt by $10 \%$, will lead to an increase in fish exports' quantity by $6.5 \%$.

Table 7. Linear and Logarithmic regression model of factors influencing Egyptian fish exports during the period (2000-2017)

\begin{tabular}{|c|c|c|}
\hline Variables & Linear Model & $\begin{array}{c}\text { Double Logarithmic } \\
\text { Model }\end{array}$ \\
\hline Constant & 1832 & 5.4 \\
\hline Fish Exports' value (x1) & $\begin{array}{c}0.06 \\
(8.7)^{* *}\end{array}$ & $\begin{array}{c}0.55 \\
(10.7)^{* *}\end{array}$ \\
\hline Domestic fish production (x2) & - & - \\
\hline Dollar exchange rate (x3) & - & 0.65 \\
\hline Fish Self-sufficiency ratio\% (x4) & - & $(2.5)^{*}$ \\
\hline F & $75.6^{* *}$ & $159.6^{* *}$ \\
\hline $\mathrm{R}^{-2}$ & 0.81 & 0.94 \\
\hline DW & 2 & 1.76 \\
\hline
\end{tabular}

Dependent Variable (Y): Fish exports' quantity - Stepwise regression method - Confidence Intervals Level $95 \%$ - Significance level (0.05)

\section{Economic evaluation of the Egyptian fish trade structure:}

Egyptian foreign fish trade can be economically evaluated through the quantitative and qualitative Egyptian fish trade balance in addition to the total and price coverage rate.

\subsection{Egyptian fish trade balance:}

Egyptian fish trade balance suffers from a continuous quantitative deficit during the study period (2000-2017). This deficit ranged between a minimum of (128.4) thousand tons in 2009and a maximum of about (331.9) thousand tons in 2017, where the annual average deficit reached to about (238) thousand tons.

The quantitative deficit resulted in a value deficit that reached to a minimum of (414) million in 2002, and to a maximum of about (9.43) billion in 2017, with an annual average of about (2.55) billion pounds, which indicates that the Egyptian balance of payments for fish still suffers from a deficit and fish exports are still unable to cope with fish imports. 


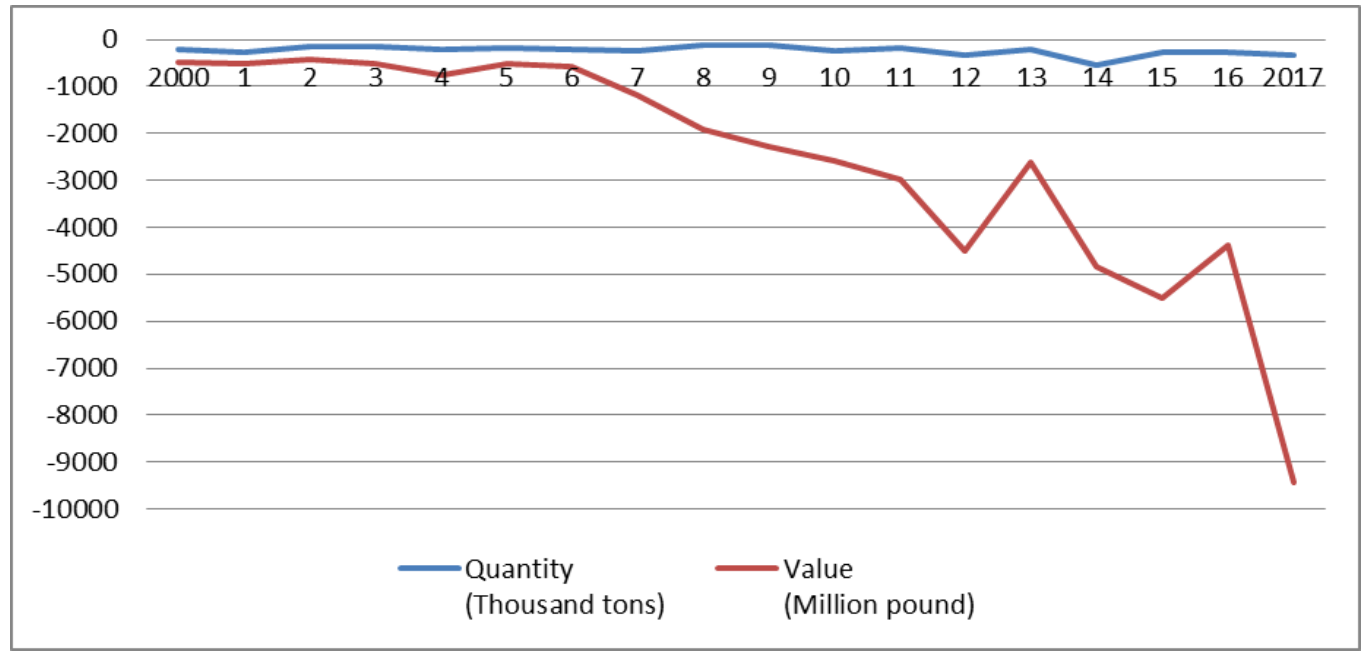

Figure 1. Fish trade balance during the period (2000-2017) (Source: data in Table 8)

\subsection{Total and price coverage rate:}

The coverage rate of fish either total or price coverage rate, reflects the importance of fish exports in facing fish imports.

There are two types of coverage rate (Hassan, 2000). The first one is the price coverage rate, which means to what extend the unit price of exports can cover the unit price of imports, or in other words, what quantity can be achieved by the value of a ton of fish exports from fish imports.

Price coverage rate $=($ unit price of exports/ unit price of imports $) * 100$

As for the second type, it is the total coverage rate; it means the ability of the value of the total exports of a particular commodity to achieve the largest possible amount of imports.

Total coverage rate $=($ value of exports of the commodity/ value of imports of the commodity) $* 100$

It is implied from table 8. that the Egyptian fish price coverage rate reached to a maximum of about $205 \%$ in 2001 and then began fluctuating between increase and decease until it reached a maximum again in 2014 with $202 \%$, and then began to decline until 2017. The price coverage rate above 100 indicates that Egyptian fish exports are luxury species with high prices and these prices cover the price of a ton of imports that has low prices.

Total coverage rate of fish in Egypt reached to a minimum of about $0.73 \%$ in 2004, while reached to its maximum of about $12.3 \%$ in 2013. The annual average of the total fish coverage rate was about $4.92 \%$ during the study period. It is implied also from table (8) that the total fish coverage rate increases by increasing the value of total fish exports over its total fish imports, whereas Egypt generally suffers from a decrease in the ratio of total fish coverage rate because it is a net imported country of fish, and it exports a limited amount of luxury fish. 


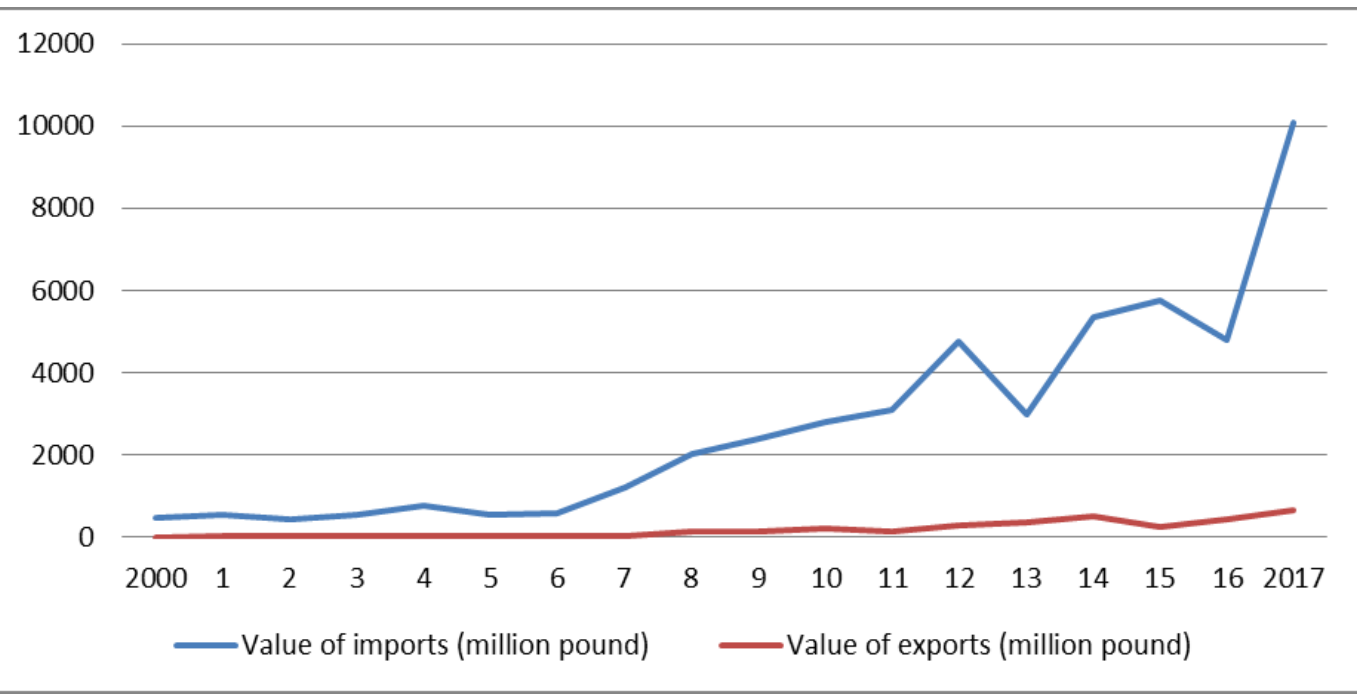

Figure 2. Value of fish imports and exports during the period (2000-20017)

Source: data in Table (8)

Table 8. Fish trade balance, total and price coverage rate during the period (2000-2017)

\begin{tabular}{|c|c|c|c|c|c|c|c|c|}
\hline \multirow[b]{2}{*}{ Years } & \multicolumn{2}{|c|}{ Imports } & \multicolumn{2}{|c|}{ Exports } & \multicolumn{2}{|c|}{ Coverage rate } & \multicolumn{2}{|c|}{ Fish trade balance } \\
\hline & $\begin{array}{c}\text { Price of ton } \\
\text { (Thousand } \\
\text { pound) }\end{array}$ & $\begin{array}{c}\text { Value } \\
\text { (Million } \\
\text { pound) }\end{array}$ & $\begin{array}{c}\text { Price of } \\
\text { ton } \\
\text { (Thousand } \\
\text { pound) }\end{array}$ & $\begin{array}{c}\text { Value } \\
\text { (Million } \\
\text { pound) }\end{array}$ & $\begin{array}{c}\text { Price } \\
\%\end{array}$ & $\begin{array}{c}\text { Total } \\
\%\end{array}$ & $\begin{array}{c}\text { Quantity } \\
\text { (Thousand } \\
\text { tons) }\end{array}$ & $\begin{array}{c}\text { Value } \\
\text { (Million } \\
\text { pound) }\end{array}$ \\
\hline 2000 & 2.23 & 476.41 & 4.30 & 4.13 & 193 & 0.87 & -212.67 & -472.28 \\
\hline 2001 & 2.05 & 533.92 & 4.20 & 5.12 & 205 & 0.96 & -259.78 & -528.8 \\
\hline 2002 & 2.75 & 423.97 & 3.90 & 9.98 & 142 & 2.35 & -151.44 & -413.99 \\
\hline 2003 & 3.33 & 543.56 & 5.90 & 18.47 & 177 & 3.40 & -159.87 & -525.09 \\
\hline 2004 & 3.42 & 755.12 & 2.90 & 5.54 & 85 & 0.73 & -219.09 & -749.58 \\
\hline 2005 & 2.77 & 523.59 & 4.50 & 23.04 & 162 & 4.40 & -183.88 & -500.55 \\
\hline 2006 & 2.85 & 593.07 & 4.80 & 19.44 & 168 & 3.28 & -203.95 & -573.63 \\
\hline 2007 & 4.72 & 1221.89 & 5.80 & 25.64 & 123 & 2.10 & -254.58 & -1196.25 \\
\hline 2008 & 14.85 & 2034.89 & 18.80 & 126.52 & 127 & 6.22 & -130.27 & -1908.37 \\
\hline 2009 & 17.70 & 2407.74 & 18.40 & 139.66 & 104 & 5.80 & -128.41 & -2268.08 \\
\hline 2010 & 10.82 & 2780.59 & 18.00 & 190.8 & 166 & 6.86 & -246.4 & -2589.79 \\
\hline 2011 & 17.07 & 3106.08 & 14.70 & 139.5 & 86 & 4.49 & -172.51 & -2966.58 \\
\hline 2012 & 14.24 & 4768.9 & 17.10 & 270.35 & 120 & 5.67 & -319.19 & -4498.55 \\
\hline 2013 & 12.65 & 2984.49 & 17.90 & 366.06 & 142 & 12.27 & -215.55 & -2618.43 \\
\hline 2014 & 9.17 & 5354.32 & 18.50 & 518 & 202 & 9.67 & -556 & -4836.32 \\
\hline 2015 & 19.44 & 5752.97 & 12.40 & 235.6 & 64 & 4.10 & -277 & -5517.37 \\
\hline 2016 & 15.45 & 4804.76 & 9.05 & 432.68 & 59 & 9.01 & -263.19 & -4372.08 \\
\hline 2017 & 27.49 & 10087.3 & 18.50 & 649.54 & 67 & 6.44 & -331.89 & -9437.76 \\
\hline Average & 10.17 & 2731 & 11.09 & 176.7 & 133 & 4.92 & -238 & -2554 \\
\hline
\end{tabular}

*Fish trade balance calculated from Exports and Imports' quantity and value in table (2) and (5)

Source: General Authority for Fish Resources Development, Fish Statistics Book, separate numbers. 


\section{CONCLUSION}

Despite the increase in domestic production of fish during the past years, Egypt still faces a deficit in meeting consumption needs, which is covered by a huge amount of imports. It is clear in order to reduce the amount of imported fish to Egypt, is to work on increasing the ratio of fish self-sufficiency rate, where it can be achieved by increasing domestic production on one hand, and rationalizing consumption on the other hand.

There is a great opportunity for Egypt to expand its fish exports in terms of quantity and value, whereas fish exports' quantity is grown by a rate of $18.6 \%$ and fish exports' value is grown by a rate of $28 \%$ annually, and the price of these exports are relatively high and mostly for luxury species of fish that can cover tons of fish imports with low prices.

The study recommends the following for enhancing the Egyptian fish trade balance:

1. A development program aims at increasing fish production in general and the most consumed fish species in particular, taking into account the expansion of fish cultivation in fish farms in addition to natural fisheries, protecting it from pollution and overfishing, which leads to increased production and stability of fisheries.

2. Developing and increasing reliance on the internal markets in order to reduce fish imports and increase exports, which leads to reducing the fish trade deficit.

3. With the fact that it is not possible to significantly increase the production of exportable fish in Egypt, it is necessary to focus on expanding high-quality fish exports and high-quality fish products.

\section{REFERENCES}

Abdel Tawab, Y.E. (2016). An economic study of fish production and marketing in Fayoum Governorate, Ph.D. thesis, Department of Agricultural Economics, Faculty of Agriculture, Fayoum University.

Allen, R.G.A. (1972). Mathematical Analysis for Economists. Macmillan St, Martin Press London, 1972.

Fabrizio, N., Alessandra, B. and Arina, M. (2015). Analysis of the determinants of international seafood trade using a gravity model. J. of Marine Policy, 60 (2015) 98106.

FAO. (2019). Globefish Highlights - A quarterly update on world seafood markets, available at: http://www.fao.org/3/ca5307en/ca5307en.pdf

Feidi, I. H. (2003). Impact of international fish trade on food security in Egypt. Report of the expert consultation on international fish trade and food security, FAO Fisheries Report No. 708, available at: http://www.fao.org/3/Y4961E/y4961e0b.htm

GAFRD. (2016). General Authority of Fish Resources Development. Fish Statics Year Book. Ministry of agriculture, Egypt, 2017. 
Hassan, N. E. (2000). An economic study of the potentials for the development of Lake Burullus, Ph.D. thesis, Department of Agricultural Economics, Faculty of Agriculture, Saba Pasha, Alexandria University.

Nawar, I. A. (1976). Food and Nutrition, New Publications House, Alexandria.

Suleiman, S. A. (2016). Egyptian Foreign Trade of Fish Products, Geographical Distribution and Economic Indicators, Alexandria Journal of Agricultural Sciences, Vol. 61, issue 5. 